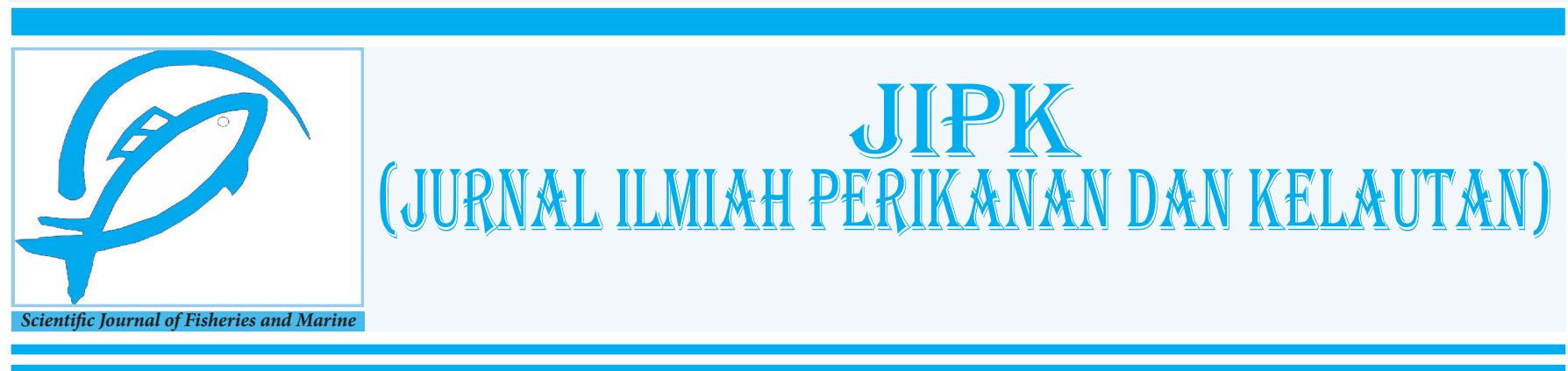

Short Communication

\title{
Redescription of Bactronophorus thoracites Gould (1856) and Bankia gracilis Moll (1935) from Sabah Waters, Malaysia, with Short Ecological Notes and Measurements Metrics
}

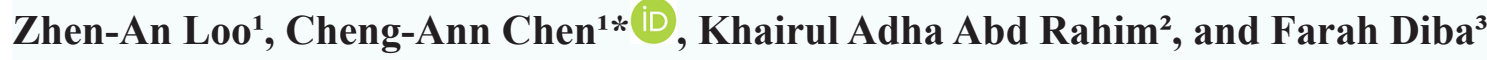

${ }^{1}$ Borneo Marine Research Institute, Universiti Malaysia Sabah, Jalan UMS, Kota Kinabalu, Sabah, 88400. Malaysia ${ }^{2}$ Department of Aquatic Sciences, Faculty of Resource Science and Technology, Universiti Malaysia Sarawak, Kota Samarahan, Sarawak, 93400. Malaysia

${ }^{3}$ Forestry Faculty, Tanjungpura University, Pontianak, West Kalimantan, 78124. Indonesia

\section{OPEN \\ ACCESS}

\section{ARTICLE INFO}

Received: Juny 14, 2021

Accepted: September 16, 2021

Published: September 25, 2021

\section{*) Corresponding author: \\ E-mail: chengann@ums.edu.my}

Keywords:

Marine wood borers

Water Parameters

Taxonomy

This is an open access article under the CC BY-NC-SA license (https://creativecommons.org/ licenses/by-nc-sa/4.0/)

\begin{abstract}
Mollusc wood-borers are classified into two groups: pholads and teredinids. While pholads have a limited distribution to temperate and tropical marine waters, teredinids are found worldwide. However, limited info on the taxonomy was documented on the marine wood borer in Sabah, Malaysia. Present study focuses on determining the wood borer species from Sabah waters, Malaysia. Samples were collected from fallen tree debris in the mangrove at Kota Kinabalu, Kuala Penyu and W.P. Labuan during low tide and water quality parameters were taken in-situ from all three sampling sites. Specimen identification was carried out by observing the physical characteristics of the pallets which are unique between genuses. The species Bactronophorus thoracites was identified from the Kota Kinabalu sampling site and species Bankia gracilis were found in both the Kuala Penyu and W.P. Labuan sampling site. The pallet of $B$. thoracite are of "dagger-andsheath" shape, it is $26 \mathrm{~mm}$ in length, with blade measuring $10 \mathrm{~mm}$ in length, basal cup $4 \mathrm{~mm}$ in length and stalk $12 \mathrm{~mm}$ in length. The pallet of B.gracilis is characterized by the dark periostacum covering the 3-lobbed upper margin of the calcareous portion of the inner face of the cone, the pallet is $20 \mathrm{~mm}$ in length, with the blade and stalk both measuring $10 \mathrm{~mm}$ in length. The present study described two species of marine wood borers namely B. thoracites and B. gracilis in Sabah and W.P. Labuan with some measurement metrics and ecological parameters that were missing from previous studies that aided the process of species identification in future.
\end{abstract}

Cite this as: Loo, Z, A., Chen, C. A., Rahim, K. A. A., \& Diba, F. (2022). Redescription of Bactronophorus thoracites Gould (1856) and Bankia gracilis Moll (1935) from Sabah Waters, Malaysia, with Short Ecological Notes and Measurements Metrics. Jurnal Ilmiah Perikanan dan Kelautan, 14(1):150-159-122. http://doi.org/10.20473/jipk.v14i1.26825 


\section{Introduction}

Marine wood borers are wood boring organisms that belong to two phyla namely mollusca and crustacea, and both phyla can live in seawater and brackish water (Rajapakse, 2016; Borges et al., 2012). Among these two phyla, there are four kinds of wood-boring organisms, two of which belonging in crustacea and the other two in mollusca. Mollusc wood borers comprise of the species belonging to pholads and teredinids, although the distribution of pholads are limited to temperate and tropical marine waters, teredinids are widespread throughout the world (Sivrikaya, 2019).

Wooden materials had been used for centuries to build structures to meet human needs, due to their unique characteristics such as renewability, aesthetic appearance, flexibility, high strength and elasticity under load (Sivrikaya, 2019). When a teredinid larvae settle on untreated wood, it will begin boring into the wood, the entry hole is hardly visible on the surface but the interior of the wood will be riddled with tunnels, affecting the structural integrity of the wood (Turner, 1966; Borgers et al., 2014). The damage of teredinids is most severe at the mud-line but they are able to attack wood at mid-tide as well (Sivrikaya, 2019). In addition, climate change with inclining global temperature will increase the risk of damage to wooden structures by shipworm (Paalvast and Velde, 2011). However, because crucial precise measurement metrics on the pallets and ecological parameters were lacking from earlier investigations, the researchers found themselves in a difficult scenario when it came to identification.

Distribution and abundance of shipworm is insufficient all around the world with only few studies conducted. Study of Beasly et al. (2005); Filho et al. (2008) was conducted in Brazil, Appelqvist et al. (2015) was in Sweden, Paalvast and Velde (2011) was in Netherlands, and Velásquez and Shipway (2018) was in the Southwest Pacific. In Malaysia, there were several studies on shipworms that had been conducted in the past. These studies primarily focus on the distribution and ecological aspects of shipworms. Several of the most notable researches conducted in Malaysia were done by Singh and Sasekumar (1994); Demas (2004); Roszaini and Salmiah (2014); Lee et al. (2019) and most recently Loo et al. (2019). Both Singh and Sasekumar (1994) and Demas (2004) focused on the distribution of shipworms in Lumut, Perak and Blungei Bay mangrove area, Sarawak respectively. Roszaini and Salmiah (2014) targeted on determining the resistance of five different mangrove tree species to marine wood borer attacks. The study done by Lee et al. (2019) focused on the phylogenetic placement of the shipworm species Bactronophorus thoracites. The most recent study to describe a species was done by Loo et al. (2019) describing the first record of shipworm species Dicyathifer mannii in Sabah.

The existing pictorial key that had been used for identification are depending on the characteristics of the pallets and some notable internal anatomy present in each genus but with limited morphometric information. The present study describes the species Bactronphorus thoracites and Bankia gracilis under the family Teredinidae Rafinesque, 1815 in Sabah, Malaysia with detailed measurements on the pallets to provide some morphometric information to the species of wood borers that inhabits Sabah coastal areas for future references and studies

\section{Materials and Methods}

\subsection{Sample collection}

A total of five samples were collected from dead wood debris in the mangrove area of Kota Kinabalu, Kuala Penyu, and W. P. Labuan (Figure 1). During the samplings, the physiochemical water quality of the site water was taken in-situ using a multiparameter probe (YSI Pro Plus). Specimens were collected from dead wood debris during low tide when the woods debris that were submerged during high tide were exposed; sample collection was solely carried out by splitting the wood debris with an axe and then extracting the exposed specimens (Loo et al., 2019).

\subsection{Sample identification}

Specimens were then fixed in $10 \%$ formaldehyde. Specimen identification was carried out by observing the characteristics of the pallets and using the work of Turner (1966) as reference. The pallets were then digested in $10 \%$ Hydrogen Peroxide $\left(\mathrm{H}_{2} \mathrm{O}_{2}\right)$ to dissolve any residual organic matter on the pallets, then the pallets were observed under a stereo microscope (Olympus SZ61) with a camera attachment (Xcam Alpha 61), pictures of the pallets were taken for the production of illustrations.

\subsection{Data analysis}

Measurements of the pallets were taken using computer software (analySIS, getIT, and MeasureIT). Descriptions of the pallets were made from drawings produced. The measurement metrics of the pallets on stalk length, stalk width, cone length, cone width, blade length and blade width were measured and recorded (Table 1). 


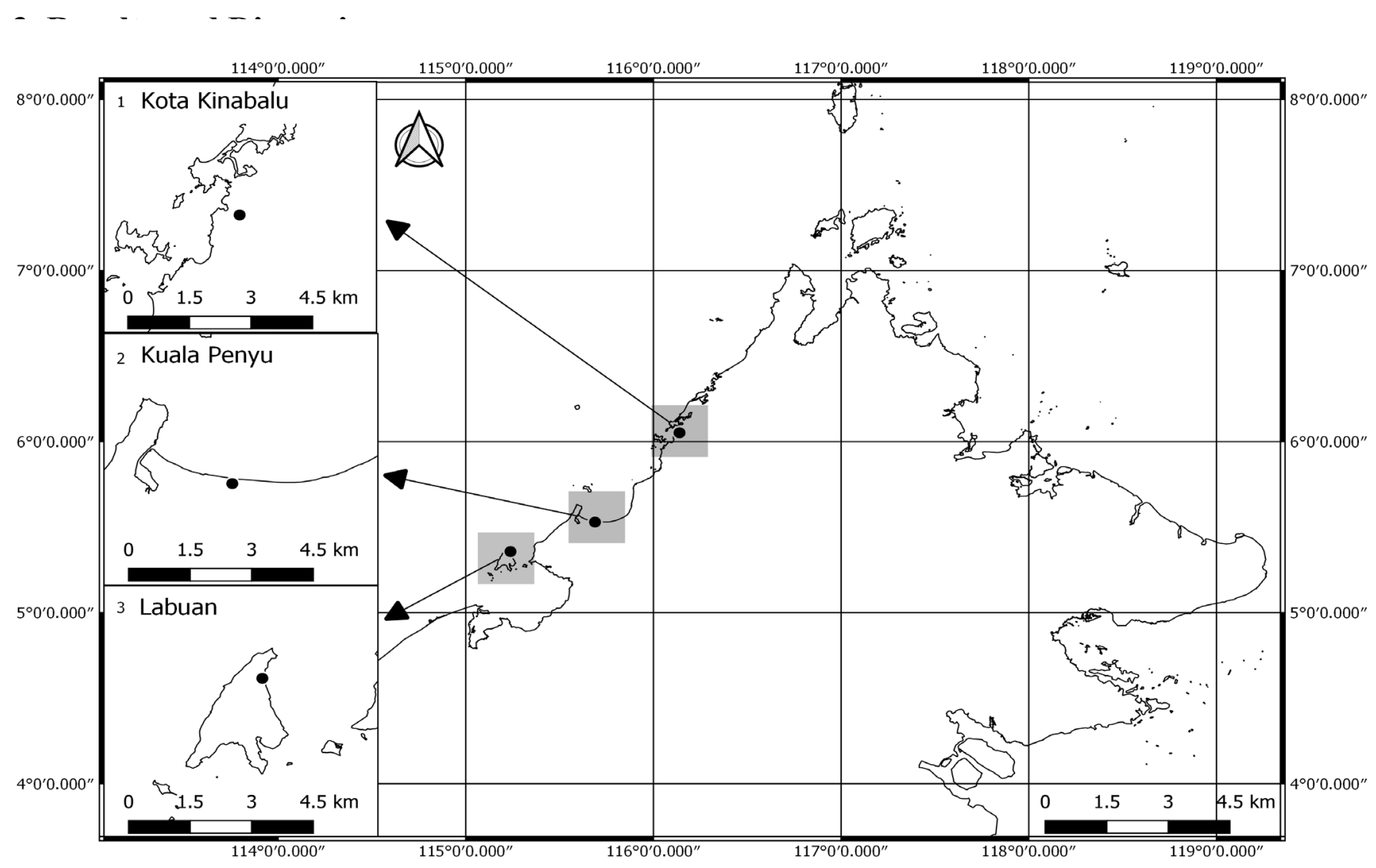

Figure 1. Map of Sabah-Borneo with sampling sites marked for Bactronophorus thoracites $^{1}$ and Bankia grac-

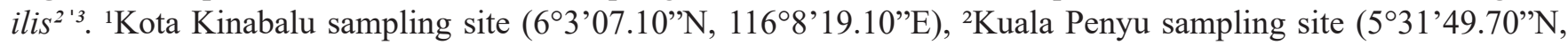
$\left.115^{\circ} 41^{\prime} 20.11^{\prime} \mathrm{E}\right),{ }^{3} \mathrm{~W} . \mathrm{P}$. Labuan sampling site $\left(6^{\circ} 58^{\prime} 03.0^{\prime}{ }^{\prime} \mathrm{N}, 115^{\circ} 14^{\prime} 16.9^{\prime} \mathrm{E}\right)$.

Table 1. Measurements for pallet of Bactronophorus thoracites and Bankia gracilis (unit mm).

\begin{tabular}{lcc}
\hline & $\begin{array}{c}\text { Bactronophorus thorac- } \\
\text { ites }\end{array}$ & Bankia gracilis \\
\hline Stalk length & 12 & 10 \\
\hline Stalk width & 2 & 0.55 \\
\hline Cone length & 4 & 11.38 \\
\hline Cone width & 11 & 4 \\
\hline Blade length & 10 & 10 \\
\hline Blade width & 2 & 4 \\
\hline
\end{tabular}

\section{Result and Discussion}

\section{Taxonomy}

\section{Order Myida}

Family Teredinidae Rafinesque, 1815

The family Teredinidae is known to have greatly reduced shell on the anterior end, a pair of specialized organs called pallets protruding from the base of the siphons and a long worm-like body. The pallets of shipworms are unique to each genus; identification of species is carried out primarily from the characteristics of the pallets.

Genus Bactronophorus Tapparone-Canefri, 1877

The pallets of Bactronophorus are of "daggerand-sheath" shape. It is asymmetric, non-segmented with a long blade extending from a basal cup. The length of the blade is almost equivalent to that of the stalk.

Locality: Kota Kinabalu, Sabah 


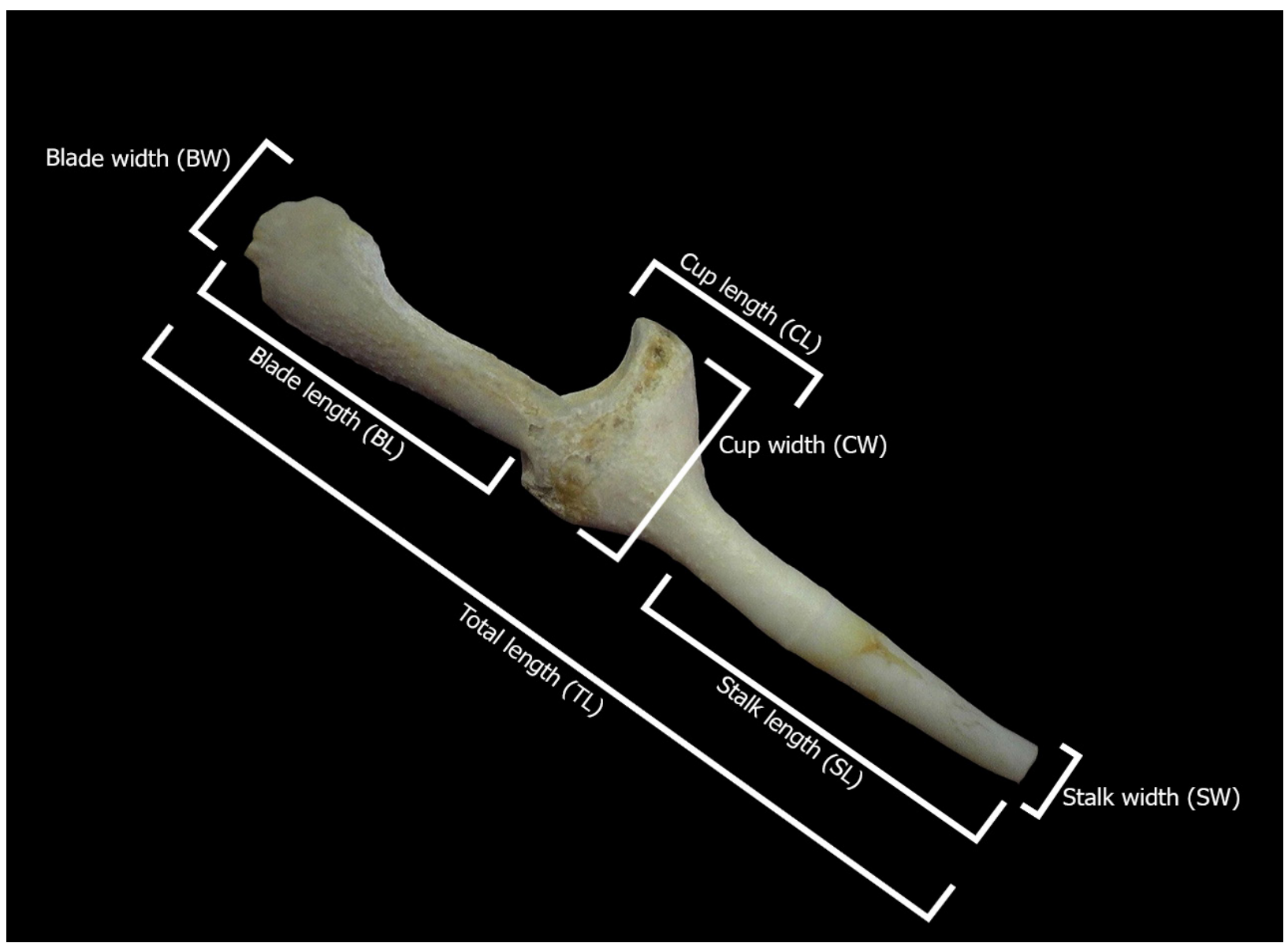

Figure 2. Right side pallet of the pair of Bactronophorus thoracites. Pallet with labels to the parts measured

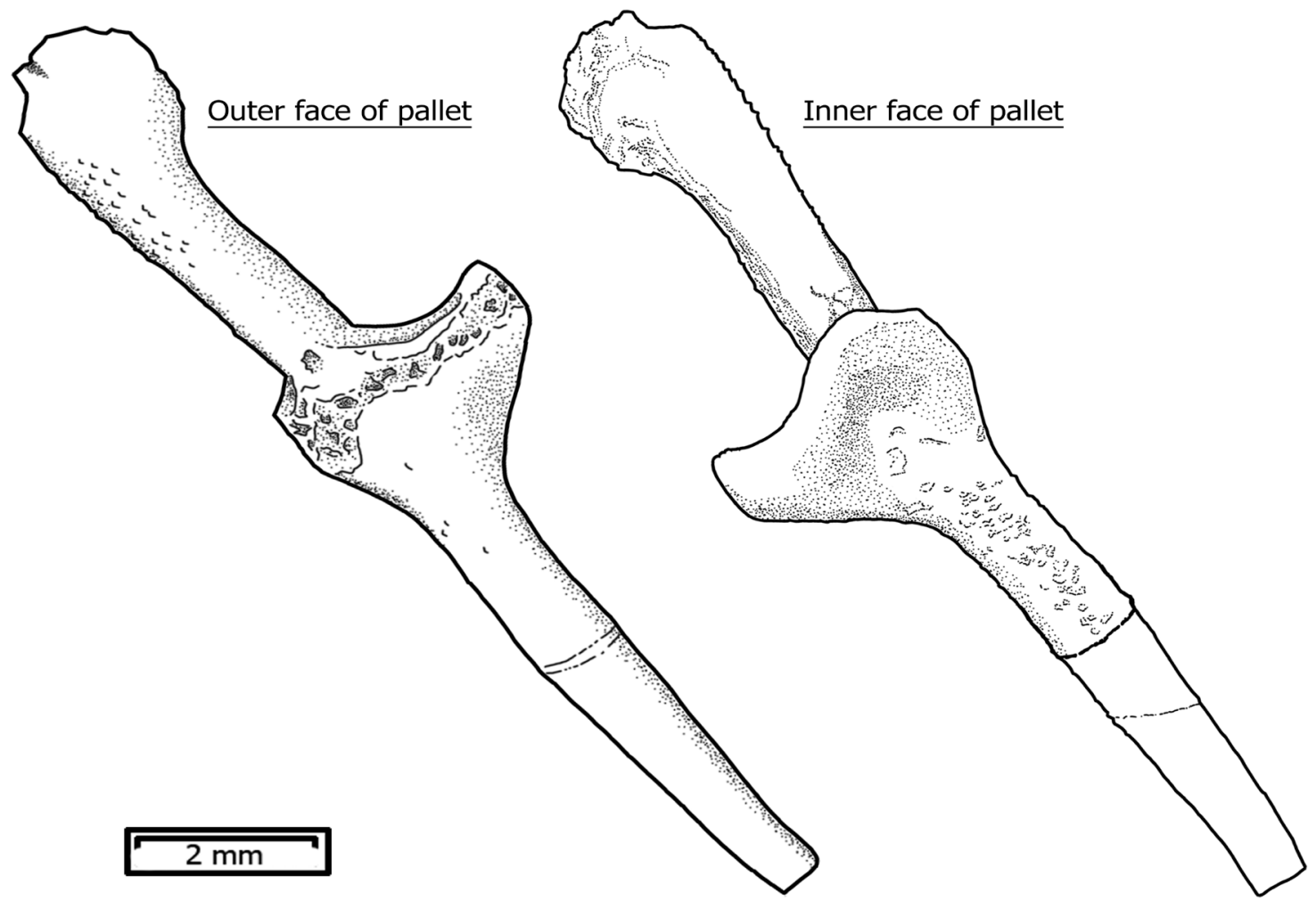

Figure 3. Illustration of the right-side pallet of Bactronophotus thoracites. Illustration of the inner and outer faces of the pallet 


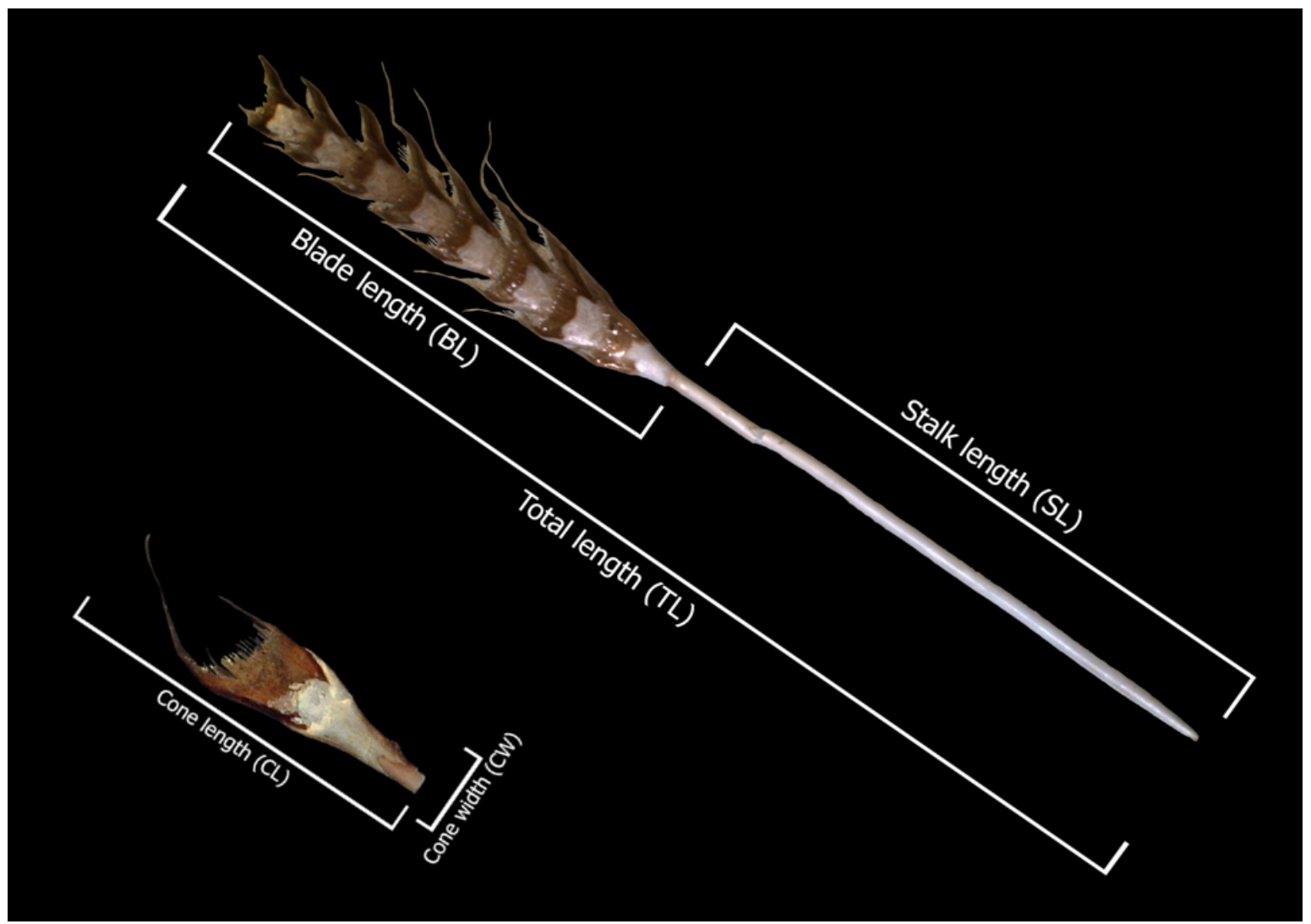

Figure 4. Right side pallet of the pair and a cone from the left side pallet of Bankia gracilis. Pallet and cone with labels to the parts measured

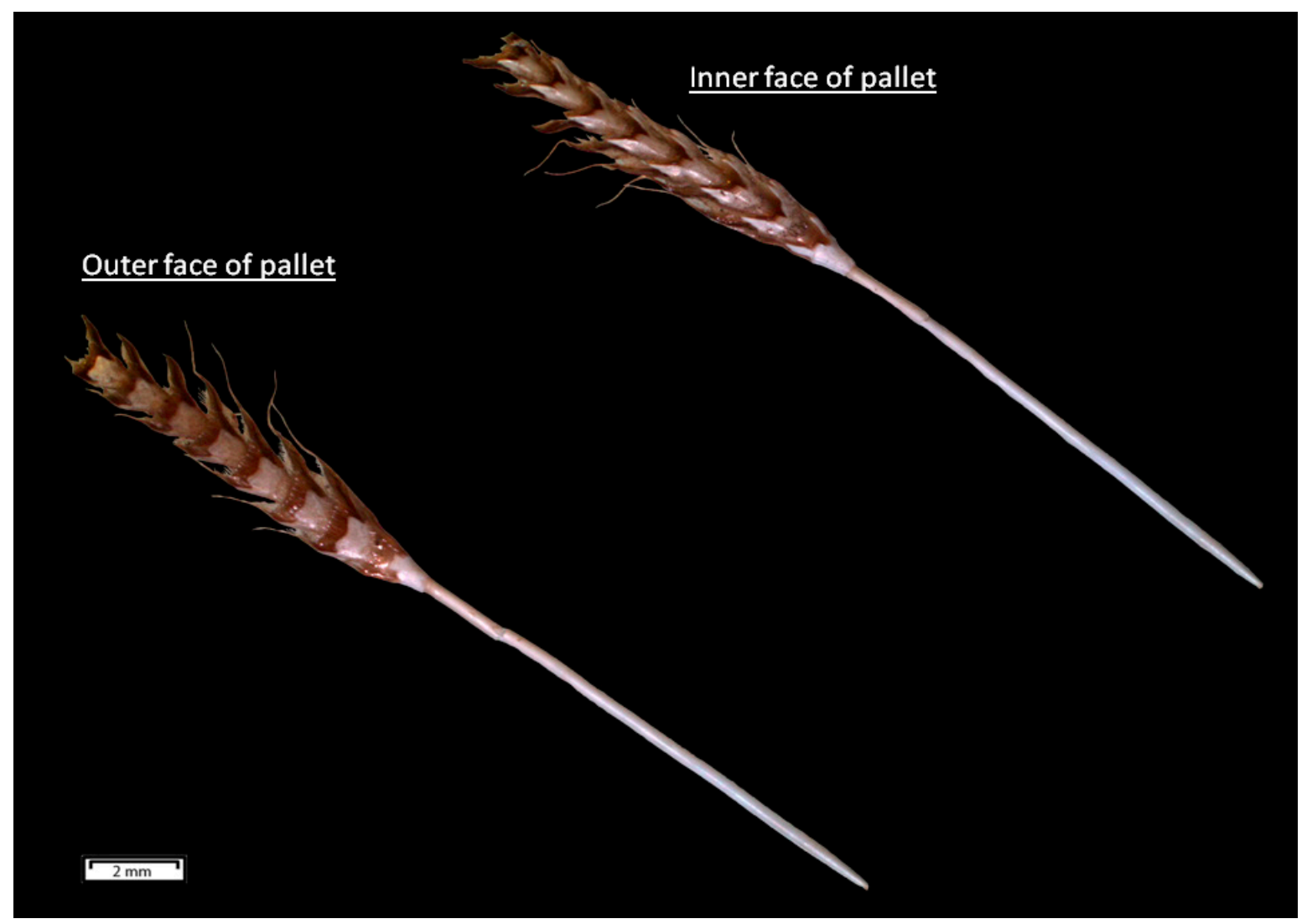

Figure 5. The right side pallet of the pair of Bankia gracilis. Comparison of features between the inner and outer face of the pallet 


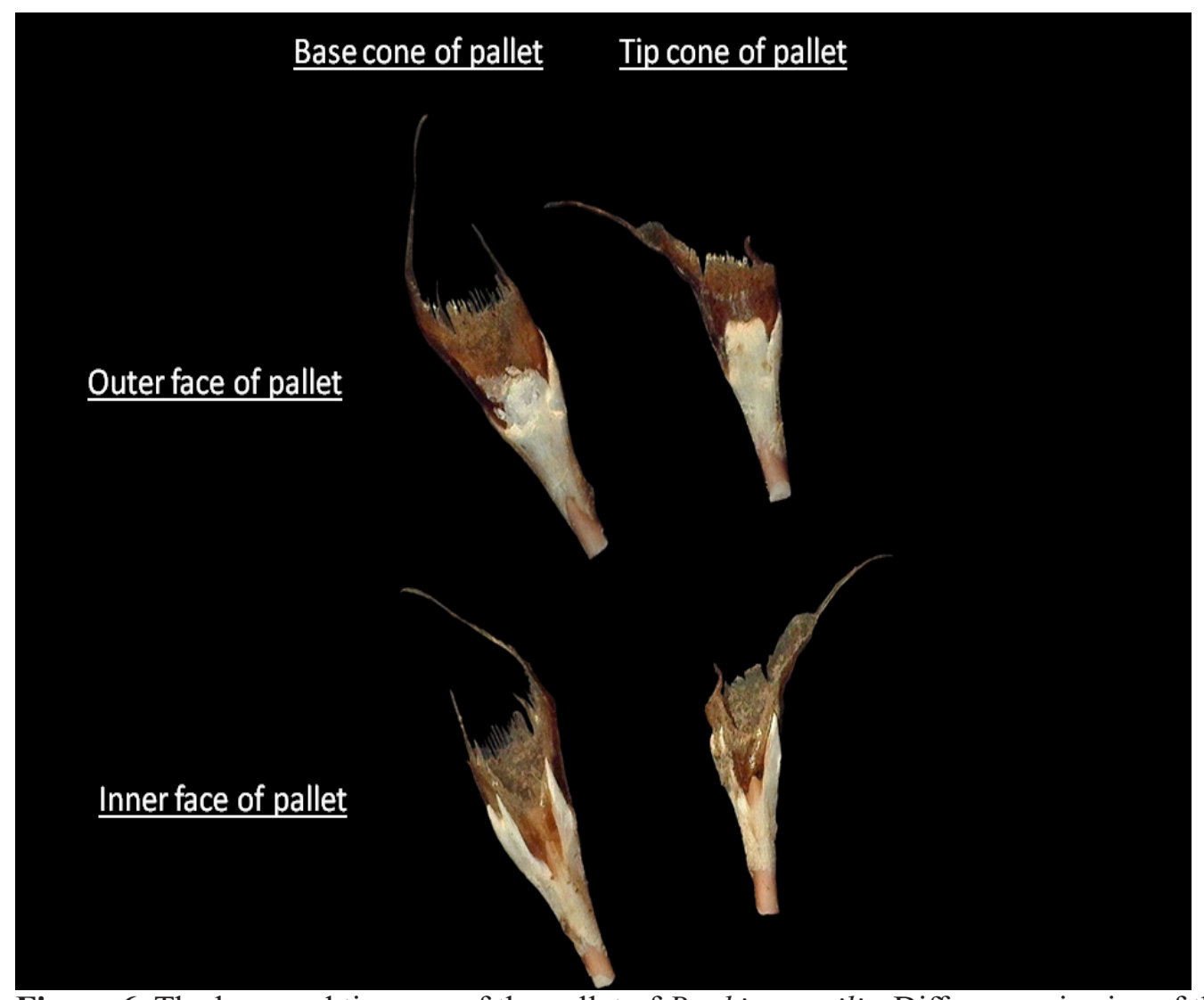

Figure 6. The base and tip cone of the pallet of Bankia gracilis. Differences in size of the base cone and tip cone of the pallet of Bankia gracilis

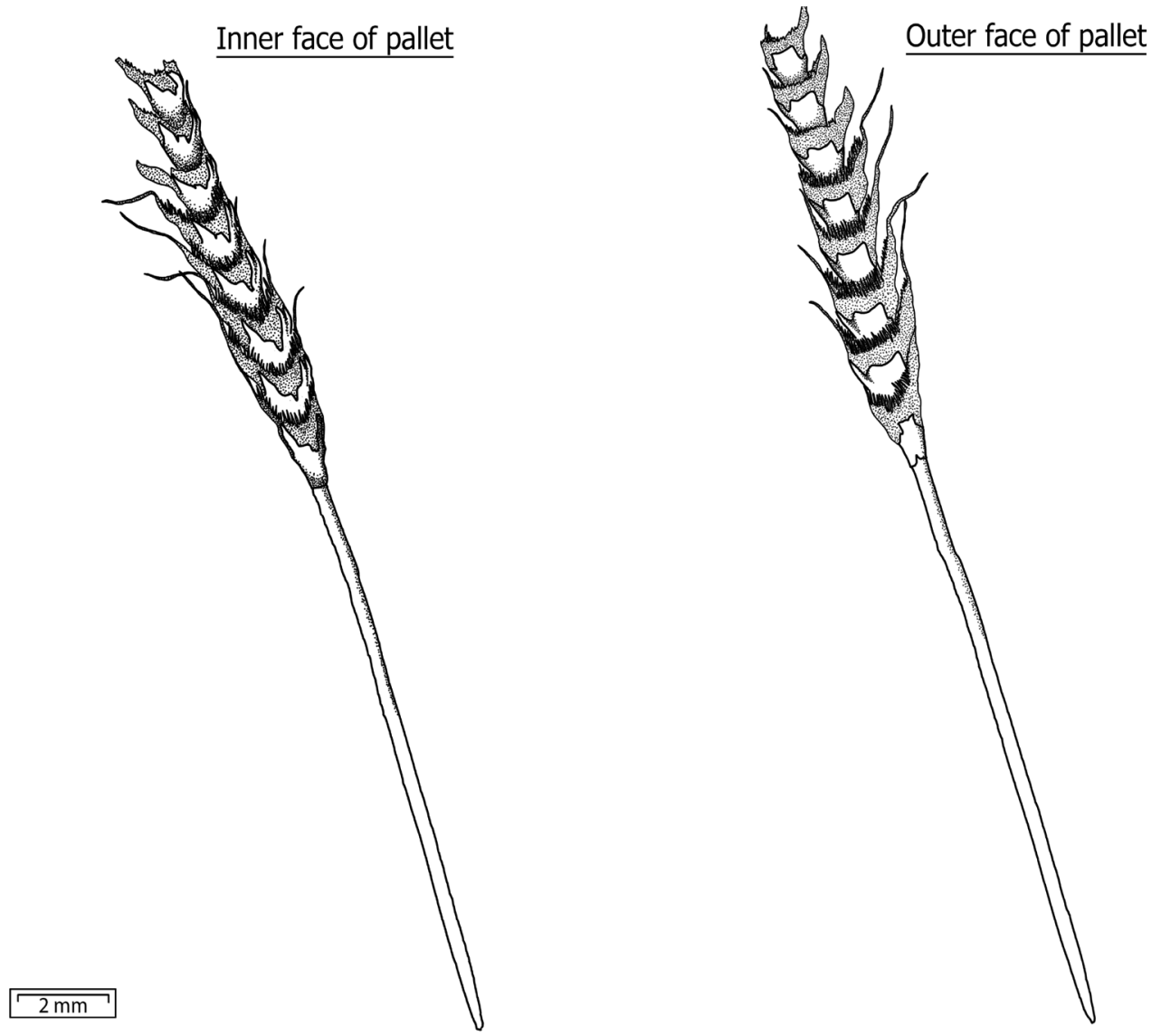

Figure 7. Illustration of the inner and outer face of the pallet of Bankia gracilis. The inner and outer faces of the pallet has different calcareous features 


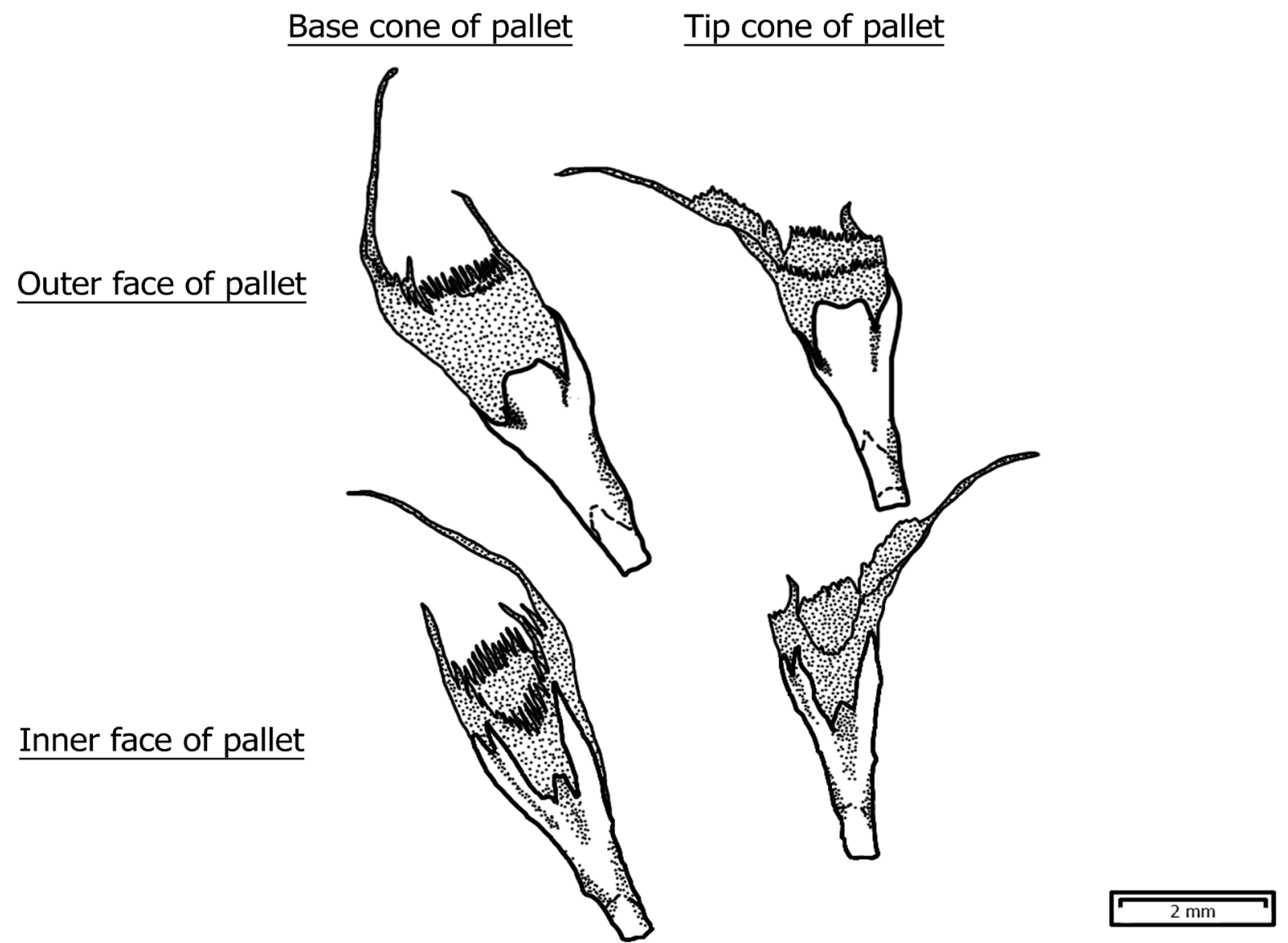

Figure 8. Illustration of the cones on the pallet of Bankia gracilis. The size of the base cone is larger than the tip cone

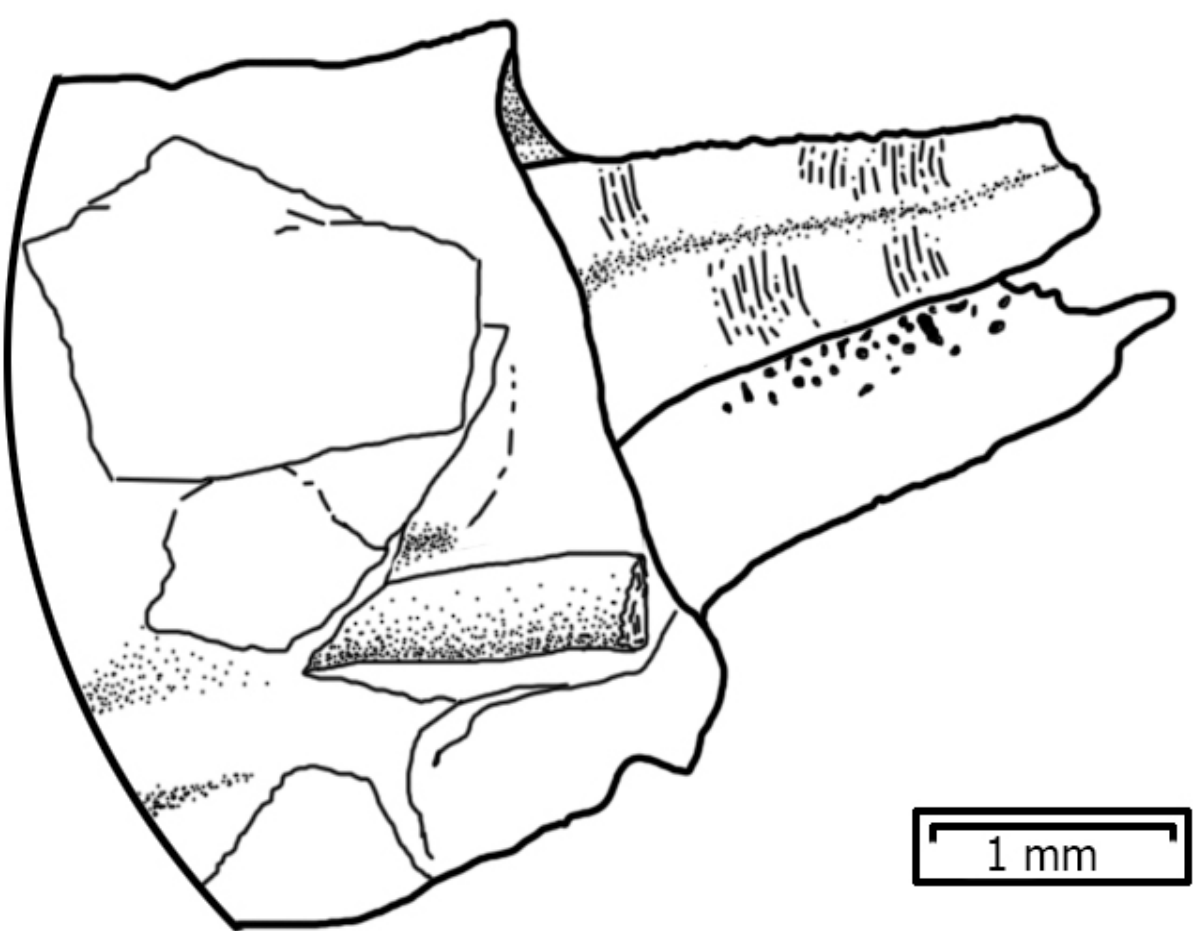

Figure 9. Magnified view of the siphons of Bankia gracilis under a microscope. Illustration of the magnified view of the siphons 
Ecological notes: Temperature: $32.1^{\circ} \mathrm{C}$; DO $8.9 \mathrm{mg} / \mathrm{L}$; Salinity: 26.08 ppt; pH: 6.69 .

\section{Description of morphometric}

The total body length of the specimen is $31 \mathrm{~cm}$, the siphons of the specimen are joined for most of its length and are $0.6 \mathrm{~cm}$ in length (Table 1 ).

The pallets of genus Bactronophorus is of "dagger-and-sheath" shape, it is non-segmented and asymmetric with a long blade extending from a basal cup. The length of the pallet is measured $26 \mathrm{~mm}$ and the stalk is $12 \mathrm{~mm}$ in length and $2 \mathrm{~mm}$ wide (Figure 2). The basal cup is $4 \mathrm{~mm}$ in length and $11 \mathrm{~mm}$ wide (Figure 3). The blade extension is $10 \mathrm{~mm}$ in length and $2 \mathrm{~mm}$ wide (Figure 3). Along the outer face of the blade, small bumps cover the surface of the blade; the coverage of the bumps may extend from the base of the blade to the tip. Some of these bumps are pointed while some are rounded (Figure 3).

\section{Genus Bankia Gray, 1842}

The genus Bankia was first described with the type species Teredo bipalmulata Lamarck, 1801 which was later accepted as Bankia bipalmulata (Turner, 1966). This genus contains 28 species and has occurrences throughout the world with exception to the polar region (Turner, 1966).

The pallets of Bankia are of "cone-in-cone" shape. It is segmented and composes of multiple individual cones stacking on each other forming the blade, the cones towards the tip gets progressively smaller. Each cone is composed of a calcareous portion which is covered by a layer of periostracum. The border of the periostracum is serrated and expands laterally forming awns.

Locality: Kuala Penyu, Sabah, and W.P. Labuan

Ecological notes: i) Kuala Penyu - Temperature: $26.9^{\circ} \mathrm{C}$; DO $2.9 \mathrm{mg} / \mathrm{L}$; Salinity: $30.35 \mathrm{ppt}$; pH: 7.7, ii) W.P. Labuan - Temperature: $32.0^{\circ} \mathrm{C}$; DO $6.2 \mathrm{mg} / \mathrm{L}$; Salinity: $22.35 \mathrm{ppt}$; pH: 7.69

\section{Description of morphometric}

The total body of the specimen was unidentified due to mismanagement of specimen, only the pallets with the siphons were remained. The siphons of the specimen are joined for most of its length and are $2 \mathrm{~mm}$ in length. The total length of the pallet was $20 \mathrm{~mm}$. The physiochemical water parameters of the sampling sites where the specimen was collected as a record.
The body of the specimen was lost due to mismanagement of specimen during collection, only the pallet remained as they were removed from the specimen to be used for identification. The specimen is identified as Bankia gracilis by the characteristic dark periostracum covering and the 3-lobbed upper margin of the calcareous portion of the inner face of the cone (Figure 6). The pallet is $20 \mathrm{~mm}$ in length with the blade and stalk both measuring $10 \mathrm{~mm}$ in length (Figure 4 and Figure 5). The blade is composed of multiple individual cones stacking on each other, the individual cones can be removed easily from one another, and the cones towards the tip of the blade is smaller than the base cone (Figure 6). The base cone is measured $4 \mathrm{~mm}$ in width. The distal surface of the cone is covered by a layer of periostracum which has a border with serrated characteristics (Figure 6). The results of the physio-chemical parameters from the two study stations indicated that Bankia gracilis potentially has a wider range of temperature $\left(26-32^{\circ} \mathrm{C}\right)$, DO (2.9-6.2 $\mathrm{mg} / \mathrm{L})$ and salinity $(22-30 \mathrm{ppt})$ tolerances.

The species Bactronophorus thoracites was first described by Gould in 1856 as Teredo thoracites. It is the only known species in the genus Bactronophorus but it was given several other names (B. edulis, $B$. filoteoi, B. subaustralis, Calobates australis, Teredo furcelloides, and T. thoracites) which were synonymised as B. thoracites (MolluscaBase, 2021). The presence of B. thoracites had been reported in Australia (Brearley et al., 2003), India (Santhakumaran and Srinivasan, 1988), Indonesia (Hendy, 2012), Malaysia (Singh and Sasekumar, 1994; Demas, 2004; Lee et al., 2019), Singapore (Tan and Woo, 2010), and Thailand (Yoosukh and Jitkaew, 1997).

The second species described in the present paper, B. thoracites, is the second largest species in terms of size after the mud boring Kuphus polythalamia (Sigwart, 2017). Gould (1856) emphasized on the great body length as well as the unique shape of the pallet of this species when compared to other described species of shipworms. Since the first discovery of $B$. gracilis in 1935 by Moll in Singapore, it had been recorded in several research studies in the region: Malaysia (Roszaini and Salmiah, 2014), India (Manavi, 2013; Santhakumaran and Srinivasan, 1988; Swain et al., 2017) and Thailand (Yoosukh and Jitkaew, 1997). The presence of this species was recorded in several habitat including polluted sites (Pati et al., 2012).

Little info on the measurements of the pallets were included in the past taxonomic studies. The general descriptions provided a vague description on the size of the pallet potentially causing some confusion in 
determining the actual size of the subjects. Therefore, the measurements of described specimens intended to provide a more accurate and insight for future species identifications (Table 1).

\section{Conclusion}

The current study is the morphometric description of the marine wood borer species Bactronophorus thoracites and Bankia gracilis in Sabah, Malaysia, and includes some measurement parameters on the pallets that were previously lacking from prior morphological descriptions as well as some environmental parameters that were previously unknown. Further studies of $B$. thoracites and $B$. gracilis may help in visualizing the ecological distribution of these two species throughout Malaysia.

Descriptions of new species of shells

\section{Acknowledgement}

Appreciations are given to Borneo Marine Research Institute, Universiti Malaysia Sabah for providing the facilities used during the progression of this research. Special thanks are also given to Miss Ng WeiLing and Miss Stephenie D. Kawi for their assistance throughout the sampling process of this research.

\section{Authors' Contributions}

All authors have contributed to the final manuscript. The contribution of each author as follow, Loo; collected the data, drafted the manuscript and designed the figures. Chen, Khairul and Fara; devised the main conceptual ideas and critical revision of the article. All authors discussed the results and contributed to the final manuscript.

\section{Conflict of Interest}

The author(s) declare(s) that there is no conflict of interest regarding the publication of this paper.

\section{Funding Information}

This research was funded by SEAMO BIOTROP through Universiti Malaysia Sabah under [SDK0031-2018] and [DIPA No. 005.9/PSRP/SC/SPKPNLT/III/2018].

\section{References}

Appelqvist, C. Havenhand, J. N., \& Toth, G. B. (2015). Distribution and abundance of teredinid recruits along the Swedish coast - are shipworms invading the Baltic Sea? Journal of the Marine Biological Association of the
United Kingdom, 95(4):783-790.

Beasley, C. R., Fernandes, C. M., Moluscos, L. D., \& Leando, A. (2005). Molluscan Diversity and Abundance Among Coastal Habitats of Northern Brazil. Ecotropica, 11:9-20.

Borgers, L. M. S., Merckelbach, L. M., Sampaio, I., \& Cragg, A. M. (2014). Diversity, environmental requirements, and biogeography of bivalve wood-borers (Teredinidae) in European coastal waters. Front Zool 11(13):1-13.

Borgers, L.M. S., Sivrikaya, R. A., Shipway, J. R., Cragg, S. M., \& Costa, F.O. (2012). Investigating the taxonomy and systematics of marine wood borers (Bivalvia: Teredinidae) combining evidence from morphology, DNA barcodes and nuclear locus sequences. Invertebrate Systematics, 26(6):572-582.

Brearley, A., Chalermwat, K., \& Kakhai, N. (2003). Pholadidae and Teredinidae (Mollusca: Bivalvia) collected from mangrove habitats on the Burrup Peninsula, Western Australia. In F. E. Wells, D. I. Walker, \& D. S. Jones (Eds.), The marine flora and fauna of Dampier, Western Australia. (pp. 345-361). Perth: Western Australian Museum.

Demas, Y. (2004). Species diversity and distribution of marine wood borers in Blungei Bay $\mathrm{man}$ grove area, Lundu Kuching Sarawak. Sarawak: Univesiti Malaysia Sarawak.

Filho, C. S., Tagliaro, C. H., \& Beasly, C. R. (2008). Seasonal abundance of the shipworm Neoteredo reynei (Bivalvia, Teredinidae) in mangrove driftwood from a Northern Brazilian beach. Iheringia. Série Zoologia, 98(1):17-23.

Gould, A. A. (1856). Descriptions of new species of shells. Proceedings of the Boston Society of Natural History, 6:11-16.

Hendy, I. W. (2012). Habitat creation for animals by teredinid bivalves in Indonesia mangrove ecosystems. Portsmouth, England: University of Portsmouth.

Lee, S. Y., Mohamed, R., \& Lamasudin, D. U. (2019). Morphology and molecular phylogenetic placement of a coastal shipworm (Bactronophorus thoracites (Gould, 1862), Teredinidae) from Peninsular Malaysia. Regional Studies in $\mathrm{Ma}$ rine Science, 29(100694):1-9. 
Loo, Z. A., Chen, C. A., Rahim, K. A. A., \& Diba, F. (2019). First record of marine wood borer (Mollusca:Teredinidae) Dicyathifer mannii Wright (1866) in Sabah, Malaysia, with detailed measurement metrics. Borneo Journal of Marine Science and Aquaculture, 3(1):37-40.

Manavi, P. N. (2013). Heavy metals in water, sediment and macrobenthos in the interdidal zone of Hormozgan Province, Iran. Marine Science, 3(2):39-47.

MolluscaBase. (2021). Bactronophorus thoracites (Gould, 1856). Accessed through: World Register of Marine Species website on May 13, 2021.

Paalvast, P., \& Velde, G.V. (2011a). Distribution, settlement, and growth of first-year individuals of the shipworm Teredo navalis L. (Bivalvia: Teredinidae) in the Port of Rotterdam area, the Netherlands. International Biodeterioration \& Biodegradation, 65(2011):379-388.

Paalvast, P., \& Velde, G. V. (2011b). New threats of an old enemy: the distribution of the shipworm $\mathrm{Te}$ redo navalis L. (Bivalvia: Teredinidae) related to climate change in the Port of Rotterdam area, the Netherlands. Marine Pollution Bulletin, 62(8):1822-1829.

Pati, S. K., Rao, M. V., Balaji, M., \& Swain, D. (2012). Growth of wood borers in a polluted Indian Harbour. World Journal of Zoology, 7(3):210215.

Rajapakse, R. (2016). Pile design and construction rule of thumb ( $2^{\text {nd }}$ ed. $)$. Oxford: Butterworth-Heinemann.

Roszaini, K., \& Salmiah, U. (2014). Resistance of five timber species to marine borer attack. Journal of Tropical Forrest Science, 27(3):400-412.
Santhakumaran, L. N., \& Srinivasan, V. V. (1988). Marine wood-borers of Andaman-Nicobar Islands with notes on control measures and on their distribution along the east coast of India. Mahasagar, 21(1):13-21.

Singh, H. R., \& Sasekumar, A. (1994). Distribution and abundance of marine wood borers on the west coast of Peninsular Malaysia. Hydrobiologia, 285(1):111-121.

Sivrikaya, H. (2019). Investigations on wood destroying marine borers in the Turkish coastal waters. Wood Industry and Engineering, 1(1):33-39.

Swain, D., Pachu, A. V., \& Rao, M. V. (2017). Biodiversity of shipworms (Mollusca: Bivalvia: Teredinidae) in the vicinity of a tropical mangrove ecosystem along Bay of Bengal, Andhra Pradesh, India. Biodiversity International Journal, 1(4):146-149.

Tan, S. K., \& Woo, H. P. M. (2010). A preliminary checklist of the molluscs of Singapore. Singapore: National University of Singapore.

Turner, R. D. (1966). A survey and illustrated catalogue of the Teredinidae (Mollusca:Bivalvia). Cambridge: Museum of Comparative Zoology. Harvard University.

Velásquez, M., \& Shipway, J. R. (2018). A new genus and species of deep-sea wood-boring shipworm (Bivalvia: Teredinidae) Nivanteredo coronata n. sp. from the Southwest Pacific. $M a-$ rine Biology Research, 14(8):806-815.

Yoosukh, W., \& Jitkaew, M. (1997). Marine wood-boring bivalves (Pholadacea) in the gulf of Thailand. Phuket Marine Biological Center Special Publication, 17(2):401-405. 